\title{
Tüketici Etnosentrizmi ve Marka İmajının Satın Alma Niyeti Üzerindeki Etkisi: Gıda Tüketicileri Üzerine Bir Uygulama
}

\author{
DOI: $10.26466 /$ opus.515217
}

\author{
Ebru Onurlubas ${ }^{*}-$ Remzi Altunışık ${ }^{* *}$ \\ * Dr. Öğr. Üyesi, Trakya Üniversitesi, Keşan Yusuf Çapraz Uygulamalı Bilimler Yüksekokulu, \\ Uluslararası Ticaret Bölümü. Keşan/Edirne/Türkiye \\ E-Posta: ebruonurlubas@trakya.edu.tr \\ ORCID: 0000-0002-2341-0788 \\ ** Prof. Dr., Sakarya Üniversitesi, İşletme Fakültesi, İşletme Bölümü, Sakarya/Türkiye \\ E-Posta: altunr@sakarya.edu.tr \\ ORCID: $\underline{0000-0001-7934-1841}$
}

$\ddot{O} z$

Kültürlerarası oluşan farklılıklar tüketicilerin bazılarının kendi ülkesinin kültürünü diğger ülkelerin kültürlerinden daha üstün görmesini sağlamakta ve buna bağlı olarak satın alma niyetlerini ortaya çıkartmaktadır. Yani tüketiciler ürünleri satın almya niyetlenirken yerli ürün olmasına dikkat etmektedirler. Bunun en büyük nedenlerinden biri ise etnik milliyetçilik olarak bilinen etnosentrizmdir. Bu çalışmada, tüketici etnosentrizmi ve marka imajının satın alma niyeti üzerindeki etkisi incelenmiştir. Bu amaçla İstanbul ilinde yaşamakta olan 18 yaşından büyük bireyler hedef alınmış ve 450 kişisye yüz yüze anket yöntemi uygulanmıştır. Anket verileri kolayda örnekleme yöntemine göre toplanmıştır. Araştırmada veri analizi, SPSS 22 ve AMOS 20 programı kullanılarak gerçekleştirilmiştir. Veriler Cronbach Alpha Katsayısı yöntemi, Normallik testi, Açıklayıcı Faktör Analizi, Doğrulayıcı Faktör Analizi, Yapısal Eşitlik Modeli kullanılarak analiz edilmiştir. Araştırma sonucunda etnosentrizm ve marka imajının ambalajlı gida ürünleri satın alma niyeti üzerinde anlaml bir etkisinin olduğu sonucuna ulaşılmıştır.

Anahtar Kelimeler: Tüketici etnosentrizmi, marka imajı, satın alma niyeti, yapısal eşitlik modeli 


\title{
The Effect of Consumer Ethnocentrism and Brand Image on Purchasing Intention: An Application on Food Consumers
}

\begin{abstract}
Intercultural differences allow consumers to consider the culture of their own country to be superior to other countries' cultures, and hence reveal their intention to purchase. In other words, when consumers intend to buy products, they pay attention to domestic products. One of the main reasons for this is ethnocentrism, which is known as ethnic nationalism. In this study, the effect of consumer ethnocentrism and brand image on purchasing intention is examined. For this purpose, individuals who are older than 18 years living in Istanbul Province have been targeted and face - to - face survey method has been conducted to 450 people. Survey data have been collected according to convenience sampling method. Data analysis has been performed by using SPSS 22 and AMOS 20 programs. The data have been analyzed using Cronbach's alpha coefficient method, normality test, explanatory factor analysis, confirmatory factor analysis and structural equation model. As a result of the research, it has been concluded that ethnocentrism and brand image have a significant effect on the purchasing intention of food products.
\end{abstract}

Keywords: Consumer ethnocentrism, brand image, purchasing intention, structural equation model 


\section{Giriş}

Günümüzde teknolojik gelişmeler ve buna bağlı olarak mal ve hizmetlerin değişimi ve artan tüketici bilinci tüketici satın alma davranışlarında farklılıklara neden olmaktadır. Satın alma davranışı, kişilerin ürün ve hizmetleri satın almaları ve kullanmaları sürecinden oluşan davranış ve tüketicilerin istek ve ihtiyaçlarını karşılamak için ürün veya hizmet aracılı̆̆ı ile problemine çözüm getirmesidir. Tüketici satın alma davranışı ise, insanların ürünleri ya da hizmetleri herhangi bir ticari amaç gütmeden, kişisel kullanım ya da hane halkı kullanımı için satın almasıdır (Pride ve Ferrell, 2000, s.195). Tüketiciler, satın alma karar süreci içerisinde ulaşılabilirlik, yeterlilik, kalite, memnuniyet, müşteri ilişkileri vb. özelliklere önem vermektedir (George ve Yaoyuneyong, 2010, s.292).

Tüketiciler bir ürünü satın almaya niyetlenirken bireysel, psikolojik ve sosyal faktörlerden etkilendikleri oranda pazarlama iletişimi faaliyetlerinden elde ettikleri bilgilerden de etkilenmektedirler. (Kocabaş vd., 1999, s.71). Tüketicilerin satın alma kararlarını etkileyen bir diğer önemli faktör ise tüketicilerin kendi aralarındaki ağızdan ağza iletişimdir. Bu sayede tüketiciler yoğun reklam karmaşasından da kurtulabilmektedirler (Cop ve Gümüş, 2009:180). Satın alma niyeti, müşterilerin herhangi bir ürünü almak için istekli olmasıdır ve müşterilerin ürünü satın alma davranışlarının tahmininde en önemli veridir (Grewal vd., 1998). Ayrıca, reklamları anlamada, tüketicilerin isteklerine ve ihtiyaçlarına uygun ürünleri tasarlamada ve pazar bölümlendirmede kullanılan, pazarlamadaki önemli bir kavramdır (Morrison, 1979). Satın alma niyetinde, demografik ve ekonomik özellikler pazarlamacılar için çok önemli bilgiler vermekle beraber tüketicilerin birbirlerinden farklı davranmalarını açıklamaya yeterli olmamaktadır. Tüketici "X" marka ürünü neden "Y" marka farklı bir ürüne tercih etmektedir? Belirli ürünleri, neden hep aynı mağazalardan almakta ve neden sürekli aynı ürünü alma niyeti göstermektedir? Bu tarz sorulara cevap bulmak oldukça zor olmaktadır. Bazı zaman, tüketicilerin kendileri bile satın alma niyetlerinin veya davranışlarının gerçek nedenini tam olarak bilememektedir (Aeker vd., 1977). Satın alma niyetine etki eden faktörler kişisel, psikolojik, sosyo kültürel faktörlerdir. Bu faktörler içerisinde gelişmekte olan ülkelerin küreselleşmesinin etkisinin gitgide artması, tüketicilerin milli duygularını 
kapsayan tüketici etnosentrizmi ve markaya ilişkin tüketicilerin zihninde genel kanı ve fikrin oluşmasını sağlayan marka imajının giderek daha önemli hale gelmesini sağlamıştır.

Amerikalı sosyolog William Graham Sumner Fransız devriminin milliyetçi etkilerinin hissedilmesinden yaklaşık bir asır sonra, 'etnosentrizm' kavramını geliştirmiştir. Shimp ve Sharma (1987) ise tüketici etnosentrizm eğilim ölçeğini (CETSCALE) geliştirmiştir. Tüketici eğilimi CETSCALE ölçeği ile ölçülmektedir. Eğilim yabancı ürünlerin tamamına karşı bir takım tutarlı davranışları ifade etmektedir (Shimp ve Sharma, 1987). Kişilerin kültürlerini ve yaşam şekillerini diğer kişilerle karşılaştırdıklarında daha fazla üstün bulma eğilimi etnosetrizm olarak tanımlanmaktadır. Bu eğilime sahip olan kişiler, kendi kültürünü odak nokta olarak bilmekte ve diğer kültürleri değerlendirmeye alırken bunu referans noktası olarak almaktadırlar (Yıldırım ve Gültaş, 2016). Etnosentrizm, dış pazarları rasyonel bir şekilde yargılamada engel taşımaktadır (Cateora vd., 2011).

Yerli olmayan yabancı ürünler uluslararası ticarette kaliteli, markasının iyi olması, fiyatı vb. niteliklerinden ötürü tüketiciler tarafından tercih edilme nedeni olsa da, iç pazarlarda rekabetin artmasıyla birlikte ülke ekonomisinin kalkınması ve milliyetçilik satın alma niyetlerini etkileyebilmektedir (Shankarmahesh, 2006). Etnosentrik tüketici eğilimi, yabancı ürünleri satın almanın uygunluğu ve ahlaki boyutuyla ilgili inançları sunmaktadır. Etnosentrik tüketiciler yerli ürünleri tercih etmektedirler. Bunun sebebi ülkelerinin ürünlerinin en iyi olduğuna inanmalarıdır. Kişilerin kendi ülkelerinde üretilen ürünleri satın almanın etik bir yükümlülük olduğunu düşünmesi, yerli ürünün kalitesinin ithal ürünlerinkinden daha yetersiz olduğu durumda bile satın almak için tüketicilere yol göstermektedir (Wang ve Chen, 2004).

Satın alma niyetini etkileyen önemli faktörlerden biri de marka ve marka imajıdır. Marka, üreticilerin veya satıcıların ürünlerinin bilinirliğini sağlayarak tanıtan, başka firmaların ürünlerinden ayırmak için kullanılan isim, sembol, terim, şekil veya tüm bunların birleşimidir. Genel olarak bunlara marka sembolü ismi verilmektedir (Pride ve Ferrel, 2000). Marka kavramının geniş bir anlamı bulunmaktadır. Ürünün şekli ve ambalajı haricinde, malı belirleyen her şey marka tanımı içinde yer almaktadır (Cemalcılar, 1987). Bir marka varlığı ve değeri bakımından ele 
alındığında; ürün/hizmetin fonksiyonel yararının ilerisinde tüketicilerine sunduğu katma değerler söz konusu olmaktadır (Jones, 1999).

Tüketicilerin markayla alakalı duydukları, tecrübeleri, reklamları, paketlemesi ve hizmetlerinden elde ettikleri bilgi toplamının, seçici algı, önceki inanışları, toplumsal normları tarafından farklılığa uğramış hali marka imajı olarak tanımlanmaktadır (Randall, 2005). Pozitif marka imajı, ürünün kalitesi, niteliği, marka bağllığı vb. değişkenler satın alma niyetini etkilemektedir (Butt vd., 2013). Tüketiciler bir ürünü satın almaya niyet ederken ürünün marka imajının kendileri için ne ifade ettiğine önem vermekte ve ona göre karar vermektedirler. Bu nedenle bir ürünün tüketiciler tarafından tercih edilmesi için marka imajı önem arz etmektedir.

Tüketiciler, yabancı ürünleri satın almaları durumunda ülkelerini kötü bir duruma sokup sokmayacaklarını düşünmektedirler. Bu nedenle tüketici etnosentrizmi, tüketici davranışları araştırmaları ve uluslararası çalışmalarda önemli bir hale gelmektedir (Liang ve Kong, 2010). Bu kapsamda araştırmada, tüketici etnosentrizmi ve marka imajının ambalajlı gıda ürünleri satın alma niyeti üzerindeki etkisini ortaya koymak amaçlanmıştır.

\section{Araştırmanın Kavramsal Çerçevesi ve Hipotezleri}

\subsection{Etnosentrizm}

İngilizcesi "Ethnocentrism" olan kavram, Türkçe'de "biz-merkezcilik'; "ırkmerkezcilik" ya da "etnosentrizm" kelimeleriyle ifade edilmektedir. Etnosentrizm Yunanca'da "millet, rrk" anlamı olan "ethnos" ve merkez anlamı olan "kentron "kelimelerinin birleşmesinden meydana gelmiştir (Özçelik ve Torlak, 2011).

Etnosentrizm kavramı, ilk defa sosyoloji alanında 1906'da William Graham Sumner tarafından kullanılmış olup, genel ifadeyle kişinin içindeki etnik grubu evrenin merkezi olarak görmesi, diğer sosyal grupları kendi grubunun bakış açısıyla değerlendirmesi ve kültürel olarak kendine benzer kişileri hiçbir şeyi düşünmeksizin kabullenmesi, farklı etnik gruplardaki kişileri istememesi olarak tanımlanmaktadır (Shimp ve Sharma, 1987; Yu ve Albaum, 2002). Evrensel bir insan davranışı olarak kabul 
edilen etnosentrizm, bütün toplumlarda, gruplarda ve bireylerde görülebilmektedir (Levine ve Campbell, 1972).

Etnosentrizm kavraminı pazarlama alanında ise ilk defa Shimp ve Sharma (1987) Amerikan tüketicilerinin yabancı ürün almalarının inanç olarak ahlaki uygunluğunu ve kendi ülkelerinde üretilen ürünlere bağl1lıklarını belirlemek için kullanmıştır (Sharma ve Shin, 1995).

Etnosentrizm genellikle grup üyelerinin kaynaşması ve dayanışmasını teşvik ettiğinden sosyal bakımdan faydalı bir işlev olarak görülmekle birlikte farklı kültür ve yaşam tarzları olan kişilere karşı üstünlük, hoşgörüsüzlük, hor görme tutumlarına sahip olabilmektedir (Caruana ve Magri, 1996). Etnosentrizm, dünyayı iki gruba ayırmaktadır ve etnosentrik açıdan gruplar birbirlerini ya "arkadaş" ya da "düşman" olarak görmekte, bulunduğu grubu elitleştirerek kayırmakta ve ayrımcılık yapmakta karşı grubu hor görmektedir (Kinder ve Kam, 2012).

\subsection{Tüketici Etnosentrizmi}

Tüketici etnosentrizmi, tüketicilerin ürün ve hizmetleri satın alma düşüncelerindeki milli duyguların etki derecesi olarak tanımlanmaktadır (Kaynak ve Kara, 2002). Diğer tanımlara göre, tüketici etnosentrizminin ana nesnesi, kültürün parçası olan üründür ve tüketici etnosentrizmi tüketicilerin ürün veya hizmet satın alırken hislerini ortaya koyan bir kavramdır (Ha, 1998). Tüketici etnosentrizmi, tüketicilerin ithal ürünlere karşı önyargılı davranarak yerli ürünleri satın almaları olarak ifade edilebilmektedir (Sharma vd., 1995).

Tüketici etnosentrizmi fonksiyonel olarak kişiye kimlik kazandırmakta, aidiyet duygusu oluşturmakta, en önemlisi ise mensubu olunan grupta hangi satın alma davranışının kabul edilebilir, hangisinin kabul edilemez olduğunun anlaşılmasını ortaya koymaktadır (Asil ve Kaya, 2013). Aynı zamanda, tüketicilerin satın alma davranışlarını etkileyerek genellikle yerel ürünlere karşı bağlılık sağlarken yabancı ürünlere karşı istememe tutumu sağlamaktadır (Mutlu vd., 2011). Yani tüketici etnosentrizmi yüksek düzeyde olan tüketici yerli ve yabancı ürün ayrımı yaparak, yabancı ürün satın alımının yerli ürüne zarar verdiğine (Schiffman ve Kanuk, 2000) yerli ekonomiye ve istihdama olan olumsuz etkileri sebebiyle, ürünlerin fiyat ve kalitelerine bakmaksızın yanlış veya uygunsuz 
olduğuna inanmaktadırlar (Xiaogang Bi vd., 2012). Ahlaki faktörler bakımından bu tüketiciler, yabancı ürün satın almanın milliyetçilik duygusuna ters olduğunu, ülkesini ve milletini sevenlerin yerli ürünleri satın alması gerektiğini düşünmektedirler. Tüketici etnosentrizmi, yabanc1 ülkelere ve bu ülkelerin ürünlerine karşı tüketicilerin algılarını ve tutumlarını olumsuz yönde etkilemektedir (Moon ve Jain, 2002).

Etnosentrik olmayan tüketiciler ise ürünün hangi yerde üretildiğini önemsememekte, kişiler kendi değer yargılarına göre ürünleri satın alma davranışı göstermektedirler. Tüketicilerin yabancı ürünlerden beklediği fonksiyonel ve sembolik değer seviyesinin, etnosentrizmin yabanc1 ürünlerin satın alınmasında ortaya çıkan negatif etkisini azalttığı belirlenmiştir (Wang ve Chen, 2004).

Etnosentrik eğilim kişiden kişiye farklılık gösterebildiği gibi, kültürden kültüre ya da bulunduğu gruptan gruba farklılık gösterebilmektedir (Witkowski, 1998).

Literatürde yapılan çalışmalar incelendiğinde etnosentrik eğilimlerin tüketici karar süreçleri üzerinde etkili olduğuna yönelik çok sayıda bulgu yer almaktadır. Evanschitzky vd., (2008) yapmış oldukları çalışmada, Almanya pazarında yerli ülke yönelimini değerlendirmiş ve güçlü bir yerli ülke yönelimi olduğunu belirlenmişlerdir. Fakat çalı̧̧mada ele alınan 14 ürün sınıfında bu yönelimlerin farklılıklar gösterdiğini tespit etmişlerdir. Netemeyer vd., (1991) yaptıkları araştırmada, CETSCALE skorlarının yabancı ürünlere karşı tüketicilerin inançlarını, tutumlarını ve davranış niyetlerini etkilediğini ortaya koymuşlardır.

Zimbabve'de yapılan araştırmada tüketici etnosentrizminin yabancı ürünlere karşı negatif ve yerli ürünlere karşı pozitif etki gösterdiği bulunmuştur. Araştırmada, tüketici etnosentrizm düzeyi yüksek bulunarak ithal mallara karşı olumsuz tutum sergilendiği belirlenmiştir (Charles ve Francois, 2016; Jiaxun ve Cheng Lu, 2015). Polonya'l1 ve Rus olan tüketicilerin etnosentrik eğilim gösterip göstermedikleri ve bu eğilimlerinin ülkelerine, demografik özelliklerine göre değişkenlik gösterip göstermediğini ve etnosentrizm derecesinin ülke orijini ile bağlantı kurulan ürün seçim kararları üzerindeki etkisi adlı yapılan çalışmada, Polonya'lı ve Rus tüketicilerin etnosentrizm skorları arasında ilişki olmadığı belirlenmiştir (Good ve Huddleston, 1995). Okechuku'ya (1994) göre; tüketiciler ilk olarak kendi ülkelerinde üretilen ürünleri satın almaktadırlar. Fakat yerli 
ürünler bulunamıyorsa ya da çeşitli özellikler bakımından yeterli değilse, o vakit tüketiciler kendi ülkeleriyle ticari ilişkileri iyi seviyede olan ülkelerin ürünlerini satın almaya niyetlenmektedirler.

Çek Cumhuriyeti ve Türkiye'de iki farklı örnek kütlede yapılan çalışmada, Türklerin yurtseverlik derecesi arttıkça tüketici etnosentrizminin arttığı ve Çeklerin ise tüketici etnosentrizmine neden olan en önemli faktörün milliyetçilik olduğu tespit edilmiştir (Balabanis vd., 2001). Bir diğer çalışmada, tüketicilerin yurtseverliliğinin olmasının, yabancı ürünler yerine yerli ürünleri tercih etmelerinde önemli bir rol oynadığı sonucuna varılmıştır (Vasella ve Fountain, 2010).

Hamin ve Elliott (2006) yaptıkları çalışmada, tüketici etnosentrizmini Endonezyalı tüketicilerin tüketici tercihlerinde ve satın alma niyetlerindeki etkilerini yerli ve yabanci markalar olan Sony, Polytron, Philips, Qantas ve Garuda örnekleriyle araştırmışlardır. Roth ve Romeo (1992)'ya göre, tüketicilerin yerli ve yabancı ürün satın alma davranışını etkileyen faktörler ürün sınıfı, ürünün menşe ülkesi hakkındaki bilgi, yurtseverlik olarak gösterilmiştir. Tüketicinin etnosentrik eğilimi ne kadar yüksekse yabancı ürün satın alma niyeti o kadar düşük ve yerli ürün satın alma niyeti o kadar yüksek olmaktadır (Klein vd., 1998; Cutura, 2006; Kavak ve Gümüşlüoğlu 2007; Evanschitzky vd., 2008).

Araştırmada kullanılan CETSCALE ölçeği, tüketicilerin etnosentrik eğilimlerini ölçmek üzere oluşturulmuş ilk ölçektir ve geçerliliği birçok çalışmada kanıtlanmıştır. Halen uluslararası geçerliliğini korumayı sürdürmektedir (Netemeyer vd., 1991).

Araştırmanın teorik altyapısı ve literatürdeki bulgulara dayanarak aşağıdaki hipotez geliştirilmiştir:

H1: Tüketici etnosentrizminin, tüketicilerin ambalajlı g1da ürünleri satın alma niyeti üzerinde anlamlı bir etkisi vardır.

\subsection{Marka İmajı}

İmaj, "gerçekliğin yaklaşık olarak bir görsel sunumu" olup, fiziksel (bir fotoğraf ya da resimde olduğu gibi) veya hayali (edebiyat ve müzikte olduğu gibi) olabilir (Yazıc1, 1996). 
Marka imaj1, üretilen ürünün hedef kitlesinde meydana gelen estetik ve duygusal izlenimlerin tamamıdır (Ker, 1998). Marka imajı, bir markanın güçlü-zayıf noktaları, olumlu-olumsuz yönleri vb. kontrol edilebilen algiların zihinde bir araya toplanmasıyla ve markayla direk veya dolaylı şekilde yaşanan deneyimlerden zaman içerisinde ortaya çıkmaktadır (Perry ve Wisnom, 2004). Marka imajı, doyum noktasına ulaşmış bir pazarda, ürün ya da hizmetin rakiplerinden ayrılarak ön plana çıkmasını sağlamaktadır (Peltekoğlu, 2004).

Biel'e (1992) göre marka imajını üç bileşene ayırmak mümkündür. Bunlar;

1) “Ürünü üreten/hizmeti verenin imajı (kurumsal imaj)",

2) "Kullanıcının/tüketicinin imajı",

3) “Ürünün/hizmetin imajı” dır.

Tüketiciler olumlu imaja sahip olan iyi bilinen marka ürünlerini satın almaktadırlar. Çünkü imajı olan markaların algılanan riskleri daha az veya algılanan değeri daha fazladır (Wang ve Tsai, 2014). Bu nedenle işletmeler ürünün güvenirliği, sağlıklı olması, kalitesi vb. konularda reklam ya da tutundurma çabalarıyla markalarının imajını iyileştirebilirler (Onurlubaş ve Öztürk, 2018).

Doyle'ye (2003) göre marka ve marka imajı aşağıda verilmiştir. Bunlar;

1) Özellikli markalar: Ürünün, fonksiyonel özelliklerine yönelik güvene dayalı bir imaja sahip olmasıdır.

2) Tutku markaları: Markayı satın alan kişilerin imajını yansıtmaktadırlar. İmaj, ürünle ilgili daha az şey iddia ederken, tüketicilerin arzuladığ 1 yaşam şekli ile ilgili vaatler sunmaktadır.

3) Deneysel markalar: Duygulara ve çağrışımlara ait bir imajı yansıtmaktadır. Başarılı deneysel markalar bireyselliği, kişisel gelişim ve fikirleri vurgulamaktadır.

Marka imajı planlaması sürecinde, etkin bir marka imajının üç işlevinin bulunduğu ileri sürülebilir (Kotler, 2009). Bunlar;

1) Ürün karakterini ve marka vaadini oluşturan tek bir mesajın iletilmesi,

2) Rakiplerin benzer mesajlarıyla karışmasını önleyici biçimde mesajin iletilmesi, 
3) Tüketicilerin zihinlerine olduğu gibi hislerine hitap eden duygusal etkininde aktarılmasıdır.

Literatürde yapılan birçok çalışmada, elde edilen bulgulara göre, marka imajının satın alma niyeti üzerinde anlamlı bir etkiye sahip olduğu bulunmuştur. Mohammadzadeh (2015); Onurlubaş (2018); Karakaşoğlu ve Arslan (2016) yaptıkları çalışmalarda marka imajının satın alma niyeti üzerinde anlamlı bir etkisi olduğunu tespit etmişlerdir.

Araştırmanın teorik altyapısı ve literatürdeki bulgulara dayanarak aşağıdaki hipotez geliştirilmiştir:

H2: Marka imajının, tüketicilerin ambalajlı gıda ürünleri satın alma niyeti üzerinde anlamlı bir etkisi vardır.

\subsection{Metodoloji}

\subsection{Araştırmanın Amacı}

Tüketici etnosentrizminin ve marka imajının ambalajlı gıda ürünleri satın alma niyeti üzerine etkisi ile ilgili literatürde çalışmalar bulunmakla birlikte yapılan çalışma, yer alan diğer çalışmaları tamamlayıcı niteliktedir. Tüketici etnosentrizminin ambalajlı gıda ürünleri satın alma niyeti ile ilgili literetürde fazla sayıda çalışmaya rastlanmaması çalışmanın literatürdeki eksikliği tamamlaması yönünde önem arz etmektedir. Çalışmada ambalajlı gıda ürünlerinin etnosentrizm açısından ele alınmasının en önemli nedenlerinden biri kültürel konteksinin yüksek olmasıdır. Bu çalışmadaki amaç, tüketici etnosentrizminin ve marka imajının, tüketicilerin ambalajlı gıda ürünleri satın alma niyeti üzerindeki etkisini ortaya koymaktadır.

\subsection{Araştırmanın Kapsamı ve Kısıtları, Örneklem}

Araştırmanın evrenini, İstanbul ilinde yaşayan kişiler oluşturmuştur. İstanbul ilinin çok kültürlü olması, ürün çeşitliliği ve tüketim çeşitliliğinin çok fazla olması sebebi ile daha geniş bir tüketici kitlesine ulaşmak için bu 
il tercih edilmiştir. Veriler 2018 yılında 450 tüketiciye uygulanan anketler aracılığ 1 ile elde edilmiştir. Araştırmanın en önemli kısıtını zaman, maddi olanaklar ve verilerin sınırlı bir bölgeden elde edilmiş olması oluşturmaktadır. Ayrıca, araştırmanın sadece ambalajlı gıda ürünlerini konu alması nedeniyle sinırlılıkları bulunmaktadır. TÜİK verilerine göre, İstanbul ilinin nüfusunun 2017 yılında 15029 231'dir (TÜİK, 2018). Ana kütle belirlendikten sonra örnek hacminin elde edilmesinde aşağıdaki formül kullanılmıştır (Arıkan, 2007);

$$
n=\frac{N * p * q}{(\mathrm{~N}-1) * \mathrm{D}+(\mathrm{p} * \mathrm{q})}
$$

$$
\begin{aligned}
& \text { N: Ana kütle (15 } 029 \text { 231) } \\
& \text { P: } 0,5 \\
& \text { q: } 0,5 \\
& \text { D: }(\mathrm{e} / \mathrm{z})^{2} \quad(0,0462 / 1,96)^{2} \\
& \text { D: Hata oran } 1 \quad(0,00055561) \\
& \text { z: istatistik değeri (1,96, \% } 95 \text { güven aralığı) } \\
& \text { n: } 450 \text { adet }
\end{aligned}
$$

Yukardaki formülle, \%0,0462 hata payı, \%95 güven aralığında yeterli örnek hacim sayısı 450 olarak tespit edilmiştir. Veri toplama yöntemi olarak tesadüfi olmayan örnekleme yöntemlerinden kolayda örnekleme yöntemi kullanılmıştır.

\subsection{Araştırma Modeli ve Hipotezler}

$\mathrm{Bu}$ araştırmada, tüketici etnosentrizmi, marka imajı, ambalajlı gıda ürünleri satın alma niyeti olmak üzere üç değişken bulunmaktadır. Tüketici etnosentrizmi ve marka imajının ambalajlı gıda ürünleri satın alma niyeti üzerinde etkisinin olabileceği düşünülerek araştırma modeli Şekil 1 'de gösterildiği gibi oluşturulmuştur.

H1: Tüketici etnosentrizminin, tüketicilerin ambalajlı gıda ürünleri satın alma niyeti üzerinde anlamlı bir etkisi vardır.

H2: Marka imajının, tüketicilerin ambalajlı gıda ürünleri satın alma niyeti üzerinde anlamlı bir etkisi vardır. 


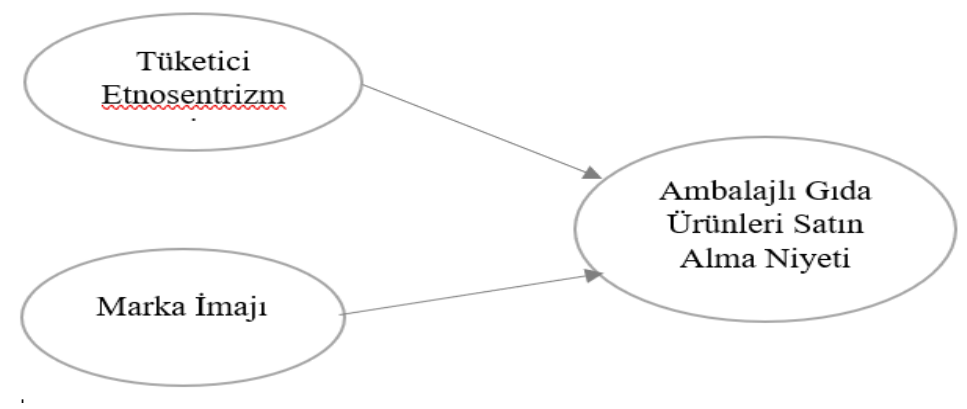

Şekil 1: Araştırma Modeli

\subsection{Verilerin toplanmas1}

Araştırmada veriler anket formu aracılığıyla toplanmıştır. Veriler İstanbul ilinde yaşayan tüketicilerle yüzyüze görüşülerek yapılan, anket uygulamalarıla elde edilmiştir. Anket formu iki bölümden oluşmaktadır. Anketin ilk bölümünde katılımcıların demografik özelliklerine ilişkin 6 soru bulunmaktadır. İkinci bölümünde tüketici etnosentrizmi ölçeğinde 17 ifade, marka imajı ölçeğinde 6 ifade ve ambalajlı gıda ürünleri satın alma niyeti ölçeğinde 5 ifade bulunmaktadır. İfadeler hazırlanırken, tüketici etnosentrizmi; Shimp ve Sharma (1987) tarafından geliştirilen 17 maddeli CETSCALE ölçeğine göre, marka imajı ölçeği; Kim vd., (2003); Salinas ve Perez (2009), satın alma niyeti ölçeği; Petroshius vd., (1987); Dodds vd., (1991); Berens vd., (2005) çalışmalarından uyarlanmıştır. Hazırlanan anket formundaki ölçeklerle ilgili sorular için 5'li Likert ölçeği kullanılmıştır. 5’li Likert ölçeğinde değerlendirme; (1) Kesinlikle katılmıyorum, (2) Katılmıyorum, (3) Kararsızım, (4) Katılıyorum, (5) Kesinlikle katılıyorum şeklinde kodlanmıştır. Ölçeklerin içsel geçerliliklerinin sağlanması için uzman görüşü alınmış ve orijinal ölçekler çeviri-tersine çeviri protokolü uygulanarak Türkçeye çevrilmiş ve son hali verilmiştir. Daha sonra, uygulamada karşılaşılacak hataları engellemek ve soruların anlaşılabilirliğini tespit etmek amacıyla 40 katılımcıya pilot uygulama yapılmış ve anlaşılmayan herhangi bir ifadenin olmadığı tespit edilerek ankete son şekli verilmiştir. Araştırmada kullanılan ölçeklerin güvenirlilikleri 
Cronbach Alpha katsayı ile ölçülmüştür. Özdamar'a (1999) göre, Cronbach Alpha değerinin 0,80-0,90 arasında olması yüksek düzeyde güvenilirlik ve 0,90-1,00 arası ise çok yüksek düzeyde güvenilirlik anlamına gelmektedir. Yapılan güvenirlik analizi sonucunda; tüketici etnosentrizminin CETSCALE ölçeğine göre Cronbach Alpha değeri 0,953 çok yüksek düzeyde güvenilir, marka imajı ölçeğinin Cronbach Alpha değeri 0,921 çok yüksek düzeyde güvenilir, ambalajlı gıda ürünleri satın alma niyeti ölçeğinin Cronbach Alpha değeri 0,861 yüksek düzeyde güvenilir bulunmuştur. Sipahi vd., (2008)'na göre Cronbach Alpha değerinin 0,70 ve üstü olduğu durumlarda ölçeğin güvenilir olduğu kabul edilmektedir. Bu bağlamda, tüm ölçekler güvenilirdir.

\subsection{Verilerin Analizi}

Araştırmada SPSS 22 ve AMOS 20 programı kullanılarak veri analizi gerçekleştirilmiştir. Ölçüm aracının güvenilirliği Cronbach alpha ile hesaplanmıştır. Güvenirlik analizinden sonra, verilerin normal dağılım gösterip göstermediğini belirlemek amacı ile normallik testi yapılmıştır. Normallik testinde veri gruplarının basıklık (kurtosis) ve çarpıklık (skewness) değerleri belirlenmiştir. Çarpıklık ve basıklık ölçüsü $+1,5$ veya $-1,5$ aralığında değerler almış olan grupların normal dağılım gösterdiği kabul edilmektedir (Tabachnick ve Fidel, 2013). Boyutların basıklık çarpıklık değerlerine bakıldığında; etnosentrizmin; çarpıklık: -0,372, basıklık: 0,344, marka imajının; çarpıklık: 0,641, basıklık: 0,151, ambalajlı gıda ürünleri satın alma niyetinin; çarpıklık: 0,115, basıklık: 0,230 olarak bulunmuştur. Sonuçlara göre araştırmadaki tüm boyutların normal dağılım gösterdiği kabul edilebilir. Araştırmada kullanılan ölçeklerin yap1 geçerliliğini test etmek amacıyla açıklayıcı faktör analizi (AFA) kullanılmıştır. DFA, belirlenen faktörler arasında yeterli seviyede ilişki olup olmadığını, değişkenlerin hangilerinin hangi faktörlerle ilişkili olduğunu, faktörlerin birbirlerinden bağımsız olup olmadığını, faktörlerin modeli açıklamakta yeterli olup olmadığını sınamak için kullanılmaktadır (Özdamar, 2004). Araştırmada, tüketici etnosentrizmi ve marka imajının ambalajlı gıda ürünleri satın alma niyeti üzerindeki etkisi Yapısal Eşitlik Modeli (YEM) tekniğiyle analiz edilmiştir. Bu bağlamda, tüketici etnosentrizmi ve marka imajı bağımsız değişken, ambalajlı gıda 
ürünleri satın alma niyeti bağımlı değişken olarak alınmıştır. YEM, doğrudan ölçülemeyen yapıları ve ölçümün potansiyel hatalarını içerebilen çoğu modeli içine alan genel bir ifade olarak tanımlanmaktadır (Raykov ve Marcoulides, 2006).

\section{Araştırma ve Bulgular}

Ankete katılanların demografik özellikleri incelendiğinde, \%53,1'inin kadın \%46,9'unun erkek olduğu görülmektedir. \%6,2'si 18-23, \%11,3'ü 24-29, \%16,2'si 30-35, \%15,3'ü 36-41, \%14,4'ü 42-47, \%13,9'u 48-53, \%12,0'si 54-59, $\% 10,7^{\prime}$ si 60 ve üzeri yaş aralığındadır. Katılımcıların, \%44,9'u evli, \%47,8'i bekâr, \%7,3'ü boşanmış olduğunu belirtmiştir (Tablo 1).

Tablo 1. Tüketicilerin Demografik Özellikleri f: Frekans, \%=yüzde

\begin{tabular}{|c|c|c|c|c|c|}
\hline Cinsiyet & (f) & (\%) & Yaş & (f) & $(\%)$ \\
\hline Kadın & 239 & 53,1 & $18-23$ & 28 & 6,2 \\
\hline Erkek & 211 & 46,9 & $24-29$ & 51 & 11,3 \\
\hline Toplam & 450 & 100,0 & $30-35$ & 73 & 16,2 \\
\hline Eğitim Durumu & (f) & $(\%)$ & $36-41$ & 69 & 15,3 \\
\hline İlköğretim mezunu & 11 & 2,4 & $42-47$ & 65 & 14,4 \\
\hline Ortaöğretim mezunu & 124 & 27,6 & $48-53$ & 62 & 13,9 \\
\hline Yüksekokul mezunu & 111 & 24,7 & $54-59$ & 54 & 12,0 \\
\hline Lisans mezunu & 117 & 26,0 & 60 ve üzeri & 48 & 10,7 \\
\hline Yüksek Lisans & 65 & 14,4 & Toplam & 450 & 100,0 \\
\hline Doktora & 22 & 4,9 & Medeni durum & (f) & $(\%)$ \\
\hline Toplam & 450 & 100,0 & Evli & 202 & 44,9 \\
\hline Meslek & (f) & $(\%)$ & Bekar & 215 & 47,8 \\
\hline Emekli & 46 & 10,2 & Boşanmış & 33 & 7,3 \\
\hline Memur & 78 & 17,3 & Toplam & 450 & 100,0 \\
\hline Özel Sektör çalışanı & 131 & 29,1 & Aile geliri (Aylık TL) & (f) & $(\%)$ \\
\hline Ev hanımı & 31 & 6,9 & 1000 TL ve altı & 44 & 9,8 \\
\hline İşçi & 119 & 26,4 & $1001-1500 \mathrm{TL}$ & 31 & 6,9 \\
\hline \multirow[t]{2}{*}{ Serbest meslek } & 17 & 3,9 & $1501-2000 \mathrm{TL}$ & 71 & 15,7 \\
\hline & & & $2001-2500 \mathrm{TL}$ & 55 & 12,2 \\
\hline Öğrenci & 28 & 6,2 & $2501-3000 \mathrm{TL}$ & 44 & 9,8 \\
\hline \multirow[t]{4}{*}{ Toplam } & 450 & 100,0 & 3001-3500 TL & 52 & 11,6 \\
\hline & & & 3501-4000 TL & 80 & 17,8 \\
\hline & & & 4001 TL ve üzeri & 73 & 16,2 \\
\hline & & & Toplam & 450 & 100,0 \\
\hline
\end{tabular}


Eğitim verilerine göre ankete katılanların, \%2,4'ü ilköğretim, \%27,6's1 ortaöğretim, \%24,7'si yüksekokul, \%26,0'sı lisans, \%14,4'ü yüksek lisans, $\% 4,9^{\prime}$ u doktora mezunudur.

Araştırmaya katılan ailelerin aylık ortalama gelirlerine bakıldığında, $\% 17,8$ 'inin 3501-4000, \%16,2'sinin 4001TL ve üstü gelire sahip olduğu görülmektedir. Meslekleri göre incelendiğinde, \%10,2'sinin emekli, \%17,3'ünün memur, \%29,1'inin özel sektör çalışanı, \%6, 9'unun ev hanımı, $\% 26,4^{\prime}$ ünün işçi, \%3,9'unun serbest meslek, \%6,2'sinin öğrenci olduğu tespit edilmiştir (Tablo 1).

Güvenilirlik analizi sonuçlarına göre 'Etnosentrizm Ölçeği' 'Marka İmajı' 'Ambalajlı Gıda Ürünleri Satın Alma Niyeti Ölçeği' için Cronbach Alpha değerlerinin tümünün 0,70 'in üstünde kabul edilebilir değerde olduğu bulunmuş ve tüm ölçeklerin güvenilir olduğu tespit edilmiştir. Cronbach Alpha değerinin 0,70 ve üzeri olması ölçeklerin güvenilirliğinin kabul edilebilir olması anlamına gelmektedir (Nunnally, 1978). Yapılan normallik testine göre tüm grupların normal dağılım gösterdiği kabul edilmiştir. Açılayıcı faktör analizinde, KMO ve Bartlett Testi sonuçlarına bakılarak yorumlanabilirliğine karar verilmiştir. Ölçüm aracının yapı geçerliliği çalışmasında 'Etnosentrizm' ölçeği için KMO (Kaiser Meyer Olkin): 0,941 ve Bartlett ( $p<0,01)$, 'Marka imaj1' ölçeği için KMO: 0,889 ve Bartlett $(\mathrm{p}<0,01)$, 'Ambalajlı Gıda Ürünleri Satın Alma Niyeti' ölçeği için KMO: 0,850 olarak belirlenmiştir. Bulunan değerlere göre, açılayıcı faktör analizinin yapılabileceği ortaya konmuştur. Araştırmada faktör analizinde bütün ölçekler ayrı ayrı faktör analizine tabi tutulduğunda, tek boyut altında toplandığından döndürme tekniği kullanılmamıştır.

Tablo 2. Araştırmada Yer Alan Ölçeklerin Güvenirlilik Analizleri

\begin{tabular}{lcc}
\hline Ölçekler & Değişken sayısı & Cronbach Alpha \\
\hline Etnosentrizm & 17 & 0,953 \\
Marka imajı & 6 & 0,921 \\
Ambalajlı gıda ürünleri & 5 & 0,861 \\
satın alma niyeti & & \\
\hline
\end{tabular}

Etnosentrizm ölçeği (CETSCALE) 17 ifade, marka imajı ölçeği 6 ifade, çevresel bilinç ölçeği 6 ifade, ambalajlı gıda ürünleri satın alma niyeti ölçeği 5 ifadeden oluşmuştur. 
Tablo 3'de görüldüğü gibi, 'etnosentrizm' ölçek maddeleri toplam varyansın \%58,596'sını açıklayan tek bir faktör altında, 'marka imajı' ölçek maddeleri toplam varyansın \%72,310'unu açıklayan tek bir faktör altında, 'ambalajlı gıda ürünleri satın alma niyeti' ölçek maddeleri toplam varyansın \%68,897'sini açıklayan tek bir faktör altında gruplanmaktadır..

Tablo 3. Açıklayıcı Faktör Analizi Sonuçları

\begin{tabular}{|c|c|c|c|c|c|c|c|}
\hline Ölçekler & Iffadeler & $\begin{array}{l}\text { Faktör } \\
\text { yüküu }\end{array}$ & KMO & $\begin{array}{l}\text { Bart- } \\
\text { lett's } \\
\text { Test of } \\
\text { Spheric- } \\
\text { ity Chi- } \\
\text { Square }\end{array}$ & $\begin{array}{l}\text { Serbest- } \\
\text { lik } \\
\text { derecesi }\end{array}$ & $\begin{array}{l}\text { Top- } \\
\text { lamaçıklanan } \\
\text { varyans (\%) }\end{array}$ & $\mathrm{p}$ \\
\hline \multirow{17}{*}{$\begin{array}{l}\text { Etno- } \\
\text { sentrizm }\end{array}$} & ETNRZ1 & 0,740 & & & & & \\
\hline & ETNSRZ2 & 0,822 & & & & & \\
\hline & ETNSRZ3 & 0,765 & & & & & \\
\hline & ETNSRZ4 & 0,674 & & & & & \\
\hline & ETNSRZ5 & 0,747 & & & & & \\
\hline & ETNSRZ6 & 0,781 & & & & & \\
\hline & ETNSRZ7 & 0,711 & & & & & \\
\hline & ETNSRZ8 & 0,799 & & & & & \\
\hline & ETNSRZ9 & 0,750 & & & & & \\
\hline & ETNSRZ10 & 0,814 & & & & & \\
\hline & ETNSRZ11 & 0,787 & \multirow{7}{*}{0,941} & \multirow{7}{*}{6018,089} & \multirow{7}{*}{136} & \multirow{7}{*}{58,596} & \multirow{7}{*}{0,000} \\
\hline & ETNSRZ12 & 0,720 & & & & & \\
\hline & ETNSRZ13 & 0,797 & & & & & \\
\hline & ETNSRZ14 & 0,786 & & & & & \\
\hline & ETNSRZ15 & 0,754 & & & & & \\
\hline & ETNSRZ16 & 0,782 & & & & & \\
\hline & ETNSRZ17 & 0,767 & & & & & \\
\hline \multirow{6}{*}{$\begin{array}{l}\text { Marka } \\
\text { imajı }\end{array}$} & MI1 & 0,908 & \multirow{6}{*}{0,889} & \multirow{6}{*}{2031,505} & \multirow{6}{*}{15} & \multirow{6}{*}{72,310} & \multirow{6}{*}{0,000} \\
\hline & MI2 & 0,827 & & & & & \\
\hline & MI3 & 0,869 & & & & & \\
\hline & MI4 & 0,745 & & & & & \\
\hline & MI5 & 0,833 & & & & & \\
\hline & MI6 & 0,909 & & & & & \\
\hline \multirow{5}{*}{$\begin{array}{l}\text { Amba- } \\
\text { lajlı gıda } \\
\text { ürünleri } \\
\text { satın } \\
\text { alma ni- } \\
\text { yeti }\end{array}$} & SATN1 & 0,500 & \multirow{5}{*}{0,850} & \multirow{5}{*}{1641,043} & \multirow{5}{*}{10} & \multirow{5}{*}{68,897} & \multirow{5}{*}{0,000} \\
\hline & SATN2 & 0,941 & & & & & \\
\hline & SATN3 & 0,939 & & & & & \\
\hline & SATN4 & 0,902 & & & & & \\
\hline & SATN5 & 0,783 & & & & & \\
\hline
\end{tabular}


KMO gözlenen korelasyon katsayıları büyüklügü ile kısmi korelasyon katsayılarının büyüklüğünü karşılaştıran bir indekstir ve bu oranın 0,50' in üzerinde olması gerekmektedir (Sharma, 1996). Çalışmada, KMO değerlerinin 0,50' nin üstünde kabul edilebilir olduğu belirlenmiştir.

Tablo 3' de faktör yüklerine bakıldığında, etnosentrizm boyutunun 17 ifadeden oluştuğu ve faktör yük değerlerinin 0,674 ile 0,822 arasında değiştiği, marka imajı boyutunun 6 ifadeden oluştuğu ve faktör yük değerlerinin 0,745 ile 0,909 arasında değiştiği, ambalajlı gıda ürünleri satın alma niyeti boyutunun 5 ifadeden oluştuğu ve faktör yük değerlerinin 0,500 ile 0,941 arasında değiştiği görülmektedir. Maddelerin ait olduğu faktörle olan ilişkisini açıklayan faktör yük değeri katsayısı için uygulamada genel olarak 0,45 üzeri değerler madde seçimi için iyi bir ölçüt olarak önerilmektedir (Büyüköztürk, 2002). Bu bağlamda, tüm boyutların faktör yükleri 0,45 'in üstünde olduğundan hiçbir ifade ölçekten çıarılmamıştır.

Tablo 4. Doğrulayıcı Faktör Analizi

\begin{tabular}{|c|c|c|c|c|c|c|c|c|}
\hline \multirow[b]{2}{*}{ 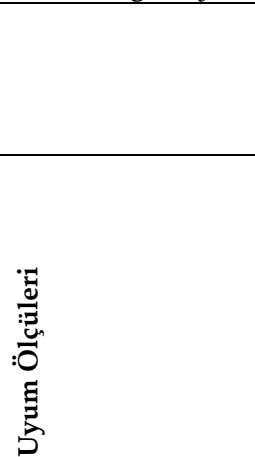 } & \multirow[b]{2}{*}{ 疍 } & \multicolumn{5}{|c|}{$\begin{array}{l}\text { Ölçeklerin Uyum } \\
\text { Değerleri }\end{array}$} & \multicolumn{2}{|c|}{$\begin{array}{l}\text { Ölçeğin Dü- } \\
\text { zeltilmiş } \\
\text { DFA Uyum } \\
\text { Değerleri }\end{array}$} \\
\hline & & 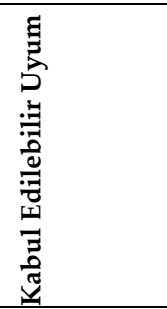 & 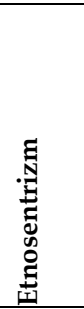 & 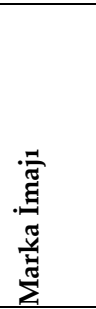 & 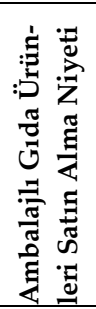 & 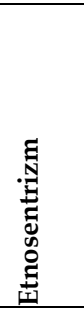 & 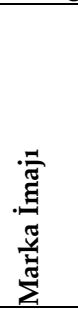 & 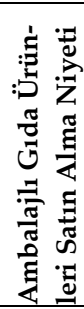 \\
\hline$\chi^{2 / d f(C M I N D F / d f)}$ & $\leq 3,4$ & $\leq 4-5$ & 9,901 & 10,719 & 3,551 & 3,430 & 2,703 & 2,083 \\
\hline GFI & $\geq 0,90$ & $0,89-0,85$ & 0,779 & 0,934 & 0,984 & 0,891 & 0,993 & 0,992 \\
\hline CFI & $\geq 0,97$ & $\geq 0,95, \geq 0,90$ & 0,823 & 0,957 & 0,992 & 0,938 & 0,997 & 0,997 \\
\hline RMSEA & $\leq 0,05$ & $0,06-0,08$ & 0,141 & 0,147 & 0,75 & 0,074 & 0,062 & 0,049 \\
\hline NFI & $\geq 0,95$ & 0,94-0,90 & 0,807 & 0,953 & 0,989 & 0,915 & 0,995 & 0,995 \\
\hline
\end{tabular}

Kaynak: Meydan ve Şeşen, 2011

Tablo 4'de DFA ölçeklerin uyum değerleri incelendiğinde, bu değerlerin iyi uyum veya kabul edilebilir uyum göstermediği tespit edilmiştir. Bu nedenle modelin uyum değerlerinin sağlanması için beta değeri düşük olan ifadeler modelden çıkarılmış ve ayrıca kovaryans 
ilişkisi kurulmuştur. Modele son hali verildikten sonra ölçeklere tekrar DFA yapılmış ve uyum değerleri incelenmiştir. Değerlere bakıldığında, tek tek boyutlara ait düzeltilmiş DFA uyum ölçütü (CMINDF, RMSEA, GFI, CFI, NFI) değerlerine ait sonuçlar, modelin veri ile uyum gösterdiğini ve ölçeğin geçerli ve güvenilir olduğunu ortaya koymaktadır.

Tablo 5. Değişkenlere Ait Ortalama ve Standart Sapma Değerleri

\begin{tabular}{lll}
\hline Değişkenler & $\begin{array}{l}\text { Aritmetik } \\
\text { ortalama }\end{array}$ & $\begin{array}{l}\text { Standart } \\
\text { sapma }\end{array}$ \\
\hline Marka İmajı & 1,6504 & 1,12346 \\
Ambalajlı gıda ürünleri satın alma niyeti & 1,2956 & 0,80291 \\
Etnosentrizm & 1,5114 & 0,83939 \\
\hline
\end{tabular}

Tablo 5'de marka imajinın standart sapması 1,12346, ambalajlı gida ürünleri satin alma niyeti 0,80291, etnosentrizm ise 0,83939 olarak bulunmuştur.

Tablo 6. Model Uyum Değerleri

\begin{tabular}{llccc}
\hline Uyum Ölçüleri & İyi Uyum & $\begin{array}{c}\text { Kabul } \\
\text { Edilebilir } \\
\text { Uyum }\end{array}$ & $\begin{array}{c}\text { Yapısal } \\
\text { Model }\end{array}$ & Yeni Yapısal Model \\
\hline$\chi 2$ df (CMIN/df) & $\leq 3, \leq 5$ & $\leq 4-5$ & 7,145 & 3,559 \\
GFI & $\geq 0,90$ & $0,89-0,85$ & 0,753 & 0,892 \\
CFI & $\geq 0,97$ & $\geq 0,95, \geq 0,90$ & 0,804 & 0,939 \\
RMSEA & $\leq 0,05$ & $0,06-0,08$ & 0,117 & 0,062 \\
NFI & $\geq 0,95$ & $0,94-0,90$ & 0,780 & 0,918 \\
\hline
\end{tabular}

Kaynak: Meydan ve Şeşen, 2011

Tablo 6'ya bakıldığında, yapısal modelde ölçeklerin uyum değerlerinin iyi uyum veya kabul edilebilir uyum göstermediği görülmektedir. Bu nedenle modelin uyum değerlerinin sağlanması için beta değeri düşük olan ifadeler modelden çıkarılmış ve ayrıca kovaryans ilişkisi kurulmuştur. (ETNSRZ 1, ETNSRZ 4, ETNSRZ 7, ETNSRZ 15, MI4 modelden çıkarılmıştır). Yeni yapısal modeldeki değerler; $\chi 2$ : Ki kare (CMIN) - df (Degrees of Freedom): 3,559; GFI (Goodness of Fit Index): 0,892; CFI (Comparative Fit Index): 0,939; RMSEA (Root Mean Square Error of Approximation); 0,075; NFI: 0,918 değerlerini aldığ1 görülmektedir. Bu 
değerlere göre, uyum iyiliği indekslerine bakıldığında tüm uyum ölçülerinin kabul edilebilir uyum sınırları içinde olduğu görülmektedir.

Şekil 2'de Tüketici Etnosentrizm ve Marka İmajının Ambalajlı Gıda Ürünleri Satın Alma Niyeti Üzerindeki Etkisi verilmiştir.

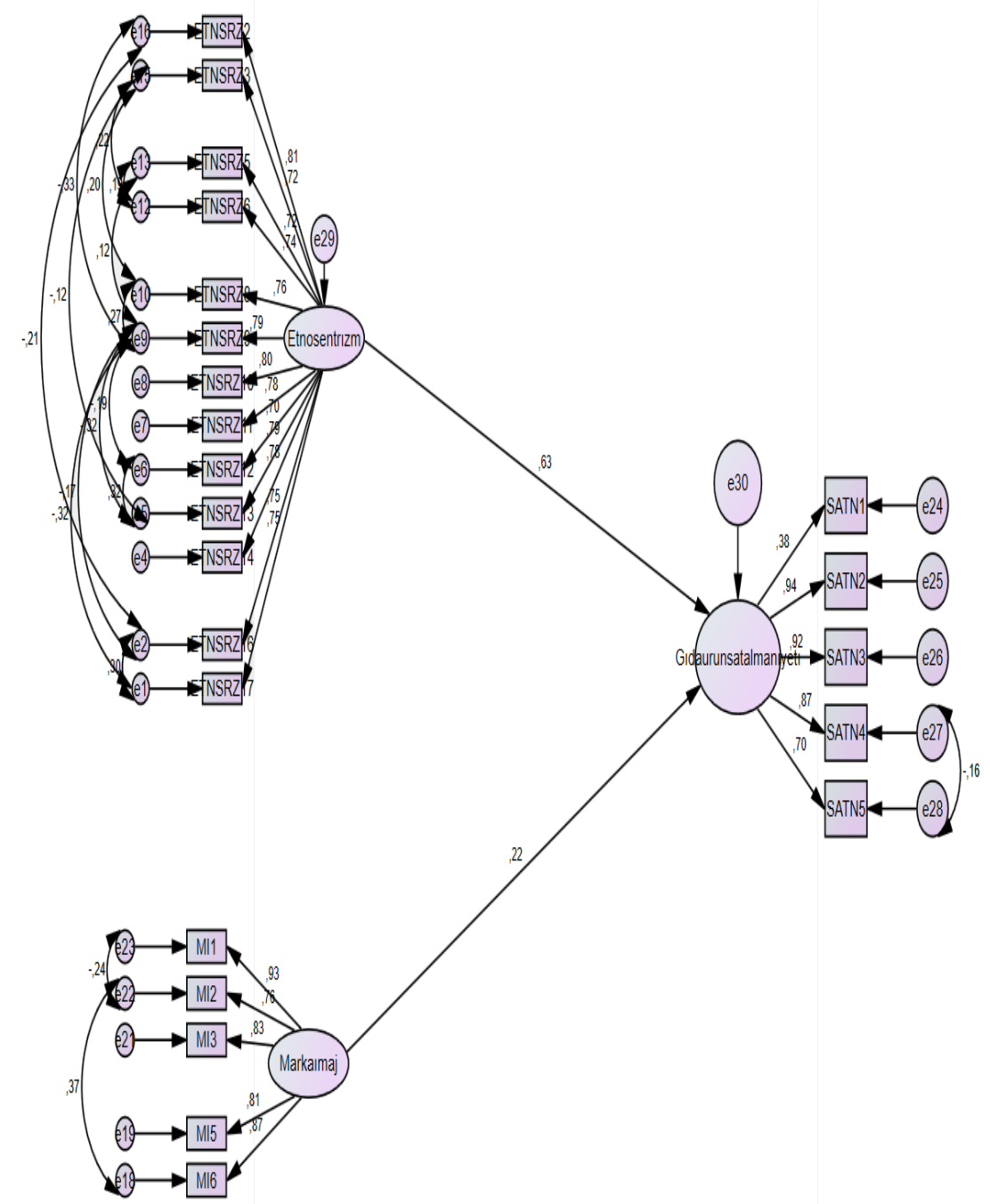

Şekil 2. Tüketici Etnosentrizmi ve Marka İmajının Ambalajlı Gıda Ürünleri Satın Alma Niyeti Üzerindeki Etkisi 
Tablo 7. Araştırma Modeli Hipotez Sonuçları

\begin{tabular}{llcccccc}
\hline Hipotez & Tahmin & $\begin{array}{c}\text { Std. } \\
\text { tahmin }\end{array}$ & $\begin{array}{c}\text { Std. } \\
\text { hata }\end{array}$ & $\begin{array}{c}\text { t } \\
\text { değeri }\end{array}$ & p & Sonuçlar \\
\hline H1 & $\begin{array}{l}\text { Tüketici } \\
\text { Etnosentrizmi } \rightarrow \\
\text { Ambalajl gida } \\
\text { ürünleri satın alma } \\
\text { niyeti }\end{array}$ & 0,350 & 0,631 & 0,048 & 7,276 & 0,000 & Kabul \\
& $\begin{array}{l}\text { Marka imaj1 } \rightarrow \\
\text { Gida ürünleri satın } \\
\text { alma niyeti }\end{array}$ & 0,090 & 0,222 & 0,019 & 4,751 & 0,000 & Kabul \\
\hline
\end{tabular}

Tablo 7'de yer alan sonuçlara göre, tüketici etnosentrizmi boyutu ile ambalajlı gida ürünleri satın alma niyeti boyutu arasındaki standardize regresyon katsayısı $\beta$ : 0,631, t: 7,276, p: 0,000 ve p anlamlılık düzeyi $\mathrm{p}<0,001$ 'dir. Bu sonuca göre H1 hipotezi kabul edilmiştir. Etnosentrizmin, ambalajlı gıda ürünleri satın alma niyeti üzerinde orta düzeyde anlamlı bir etkisi olduğu tespit edilmiştir.

Marka imajı boyutu ile ambalajlı gıda ürünleri satın alma niyeti boyutu arasındaki standardize regresyon katsayısı $\beta: 0,222, \mathrm{t}: 4,751$, p: 0,000 ve $p$ anlamlılık düzeyi $\mathrm{p}<0,05)^{\prime}$ dir. $\mathrm{Bu}$ sonuca göre $\mathrm{H} 2$ hipotezi kabul edilmiştir. Marka imajının, ambalajlı gıda ürünleri satın alma niyeti üzerinde zayıf ve anlamlı bir etkisi olduğu belirlenmiştir.

\section{Sonuç}

Çalışmada tüketici etnosentrizmi ve marka imajının ambalajlı gıda ürünleri satın alma niyeti üzerindeki etkisi incelenmiştir. Bu bağlamda, araştırmada ölçüm aracının geçerliliği için açıklayıcı faktör analizi ve boyutlar için doğrulayıcı faktör analizi uygulanmıştır. Daha sonra hipotezlerin test edilmesinde ise Yapısal Eşitlik Modeli (YEM)'den faydalanılmıştır.

Yapılan araştırmada YEM sonuçlarına göre;

Araştırma sonucunda, tüketici etnosentrizminin, tüketicilerin ambalajlı gıda ürünleri satın alma niyeti üzerinde anlamlı bir etkisi olduğu bulgusuna ulaşılmıştır. Kültürlerarası farklılıklar bazı kişilerin kendi ülkes- 
inin kültürünü diğer ülkelerin kültürlerinden üstün tutması gibi davranışları ortaya çıkartmaktadır. Kişiler bir ürünü satın almaya niyetlenirken kendi ülkelerinin ürünü olmasına yani yerli ürün olmasına dikkat etmektedirler. Bunun en büyük nedenlerinden biri etnik milliyetçilik olarak bilinen etnosentrizmdir. Etnosentrik tüketiciler kendi ülkelerinin ürünlerine milliyetçi duygularla bağlı olduklarından, kendi ülkelerinin ürünlerini diğer yabancı markalardan daha kaliteli ve üstün görmektedirler. Etnosentrik tüketiciler, bir ürünü satın alırken yerli ürünleri tercih ederek ülke ekonomisine katkıda bulunan refah seviyesinin artacağ düşüncesine sahip olan kişilerdir. Bu bağlamda, pazarlama uygulayıcılarının özellikle yüksek milliyetçi duygulara sahip olan ülkelerde, kişilerin yerli ürünleri tercih etmesini göz önüne alarak potansiyel müşterileri kendilerine çekebilmek ve böylelikle satışlarını arttırarak kâr elde edebilmek için ambalajlı gıda ürünleri üretiminde özellikle tüketici etnosentrizmine dikkat etmesi ve yerli üretime önem vermesi gerekmektedir.

Araştırmadaki diğer bir bulgu ise, marka imajının, tüketicilerin ambalajlı gıda ürünleri satın alma niyeti üzerinde anlamlı bir etkisi olduğudur. Tüketicilerin belirli markalara ilişkin algıları marka imajı olarak bilinmektedir. Tüketiciler iyi bir marka imajı olan ürün için bu ürün kaliteli, kötü bir marka imajı olan ürün için bu ürün kalitesizdir şeklinde yorumlar yapabilirler. Bu nedenle ürünlerin marka imajı önem arz etmektedir. Özellikle sağlık açısından bir hayli önem taşıyan ambalajlı gıda ürünleri için marka imajı daha fazla önem taşımaktadır. Bu nedenle gıda sektöründe faaliyet gösteren işletmeler, markanın ve ürünün imajını reklamlar aracılığı ile sağlayabilirler. Ayrıca, marka imajı yaratabilmek için işletmeler markanın ismini kısa ve anlaşılır koymalı hem göze hem kulağa hitap etmeli, bir markaya isim verirken özellikle anlamlarına dikkat etmelidirler.

Sonuç olarak elde edilen bulgulara göre, sektörde faaliyet gösteren işletmeler tüketicilerin satın alma niyetlerini arttırmak istiyorlarsa ilk olarak tüketici etnosentrizmine odaklanmaları yararlı olacaktır. Yerli firmalar etnosentrizmin sağladığı avantajdan yararlanarak daha fazla piyasada tutunabilir ve kâr paylarını arttırabilirler. Yabancı firmalarda tüketici etnosentrizmine dikkat ederek bilinçli davranmaları durumunda 
dezavantajlı durumu avantaja dönüştürebilirler. Yani, etnosentrizm konusunda bilgi sahibi olan yabancı firmalar, başarılı pazarlama stratejileri ile piyasada tutunabilirler.

Bu çalışma, tüketici etnosentrizmi ve marka imajının ambalajlı gıda ürünleri satın alma niyeti üzerindeki etkisini ortaya koyarak literatüre katkıda bulunması ve sektörde faaliyet gösteren veya bu sektörde yeni faaliyete başlayacak olan işletmelere yol göstermesi açısından önem arz etmektedir. Çalışmada verilen önerilerle, işletmelerin pazar paylarını arttırmaları ve sektörde devamlılıklarını sürdürebilmeleri amacıyla politikalarının oluşturulması sağlanabilir.

Araştırma İstanbul'daki tüketicilerle sınırlı olduğundan elde edilen sonuçlar kısıtlı olmaktadır. Bu sebeple bundan sonra yapılan çalışmalar farklı bölgelerde ve daha büyük örneklem ile yapılabilir ve ambalajlı gıda ürünleri satın alma niyetine farklı değişkenler eklenerek ilgili literatüre katkı sağlanabilir.

Araştırmadaki bulgular yalnızca ambalajlı gıda ürünlerini kapsamaktadır. Etnosentrizm ve marka imajının satın alma niyeti üzerindeki etkileri ileride yapılacak olan çalışmalarda diğer ürün kategorilerine göre farklı ürün gruplarında incelenebilir. Ayrıca sosyo demografik özelliklere göre etnosentrizm ve marka imajının satın alma niyeti üzerindeki etkileri incelenebilir. 
EXTENDED ABSTRACT

\title{
The Effect of Consumer Ethnocentrism and Brand Image on Purchasing Intention: An Application on Food Consumers
}

\author{
$*$ \\ Ebru Onurlubaş - Remzi Altunışık \\ Trakya University - Sakarya University
}

Intercultural differences allow consumers to consider the culture of their own country to be superior to other countries' cultures, and hence reveal their intention to purchase. In other words, when consumers intend to buy products, they pay attention to domestic products. One of the main reasons for this is ethnocentrism, which is known as ethnic nationalism.

In this study, the effect of consumer ethnocentrism and brand image on purchasing intention is examined. For this purpose, individuals who are older than 18 years living in İstanbul Province have been targeted and face - to - face survey method has been conducted to 450 people. Survey data have been collected according to convenience sampling method. Data analysis has been performed by using SPSS 22 and AMOS 20 programs.

The data were tested by Cronbach Alpha to determine the internal consistency and reliability of the measuring instrument, with the confirmatory factor analysis for the validity of the measurement tool, and the confirmatory factor analysis for structural validity. It was then tested with Structural Equation Model (SEM).

According to the results of SEM in the research;

As a result of the study, it was found that consumer ethnocentrism had a significant effect on consumers' intention to purchase packaged food products. Intercultural differences bring about the behavior of some people that the culture of their own country is superior to other countries' cultures. When purchasing a product, people pay attention to the fact that they are the products of their own countries and that they are domestic products. One of the main reasons for this is ethnocentrism, which is 
known as ethnic nationalism. Due to the fact that ethnocentric consumers are connected with nationalist feelings to their country's products, they consider their country's products to be higher quality and superior than other foreign brands. Ethnocentric consumers are the people who have the idea of increasing the level of welfare that contributes to the national economy by choosing domestic products when purchasing a product. In this context, marketing practitioners should pay particular attention to consumer ethnocentrism and domestic production in the production of packaged food products in order to attract potential customers by taking advantage of the fact that consumers especially in countries with high nationalist feelings generally prefer local products and hence in order to profit by increasing their sales.

Another finding of the study is that the brand image has a significant effect on consumers' intention to purchase packaged food products. Consumers' perceptions of certain brands are known as brand image. Consumers can make comments for a product with a good brand image that this product is good quality and for a product with a bad brand image that this product is poor quality. Therefore, the brand image of the products is important. Brand image is more important for packaged food products which are especially important in terms of health. For this reason, businesses operating in the food sector can provide the image of the brand and the product through advertisements. In addition, in order to create a brand image, businesses should put the brand name in a short and understandable way, appeal to both the eye and the ear, and pay particular attention to their meaning when giving a brand name.

As a result, according to the findings, if the businesses operating in the sector want to increase the purchasing intentions of consumers, it will be beneficial to focus on consumer ethnocentrism first. Domestic companies can benefit from the advantage of ethnocentrism and can hold more on to the market and increase their profit shares. Foreign companies can turn the disadvantageous situation into an advantage if they act consciously by paying attention to consumer ethnocentrism. In other words, foreign companies who have knowledge about ethnocentrism can hold on to the market with successful marketing strategies.

This study is important in terms of contributing to the literature by demonstrating the effect of consumer ethnocentrism and brand image on 
the purchase intention of packaged food products and to guide the enterprises operating in the sector or which are about to start new activities in this sector. With the suggestions given in the study, it can be ensured that the enterprises increase their market shares and establish their policies in order to maintain their continuity in the sector.

Since the research is limited to the consumers in Istanbul, the results are limited. For this reason, the studies carried out thereafter can be done in different regions and with larger samples, and the relevant literature can be contributed by adding different variables to the intention of purchasing packaged food products.

The findings of the study cover only packaged food products. The effects of ethnocentrism and brand image on the purchasing intention can be examined in different product groups according to other product categories in future studies. In addition, the effects of ethnocentrism and brand image on purchasing intention can be examined according to socio - demographic characteristics.

\section{Kaynakça / References}

Aaker, D.A, Burton H. Marcus, Dorothy Cohen (1977). Modern marketing. (New York: Random House), 3, 100.

Arıkan, R. (2007). Araştırma teknikleri ve rapor hazırlama. 6. Baskı, Isbn:9758784-35-8, Ankara.

Asil, H. ve Kaya, İ. (2013). Türk tüketicilerin etnosentrik eğilimlerinin belirlenmesi üzerine bir araştırma. İstanbul Üniversitesi Isşletme Fakültesi Dergisi, 42 (1), 113-132.

Balabanis, G., Diamantopoulos, A., Mueller, R.D., Melewar, T.C. (2001). The impact of nationalism, patriotism and internationalism on consumer ethnocentric tendencies. Journal of International Business Studies, 32 (1), 157-175.

Berens, G., Cees B.M. Van R., Gerrit, H., Van, B. (2005). Corporate associations and consumer product responses: the moderating role of corporate brand dominance. Journal of Marketing, 69(3), 35-48

Biel, A.L. (1992). How brand 1mage drives brand equity. Journal of Advertising Research, (11), 6-12. 
Butt, H. A., Nawaz, M. R., Nawaz, M. M., Tariq, M. I. ( 2013). Customer perceptions about branding and purchase intention: astudy of fmcg in an emerging market. Journal of Basic and Applied Scientific Research, 3(2), 340- 347.

Büyüköztürk Ş. (2002). Sosyal bilimler için veri analizi el kitabı. 2. Baskı. Ankara: Pegem Yayıncilık.

Caruana, Albert ve Magri, Emanuel (1996). The effect of dogmatism and social class variables on consumer ethnocentrism in Malta. Marketing Intelligence \& Planning, 14 (4), 39-44.

Cateora, Philip R., Mary C. Gilly ve Graham, J.L. (2011). International Marketing. New York: Mc-Graw-Hill Irwin.

Cemalcılar, İ. (1987). Pazarlama, kavramlar-kararlar. İstanbul: Beta Basım Yayım.

Charles, M. ve Francois D. T.F. (2016). Measuring consumer ethnocentrism: An assessment of reliability, validity and dimensionality of the cetscale in a developing market. Journal of African Business, 17(2), 188-208.

Cop, R ve Gümüş, N. (2009). Pazarlamada ağızdan ağza iletişimin tüketici davranışlarındaki rolü ve bir araştırma. Ticaret ve Turizm Eğitim Fakültesi Dergisi, 2, 179-202

Cutura, M. (2006). The impacts of ethnocentrism on consumers' evaluation processes and willingness to buy domestic vs. imported goods in the case of Bosnia and Herzegovina. South East European Journal of Economics and Business, 1(2), 54-63.

Dodds, William B., Kent B. Monroe and Dhruv G. (1991). The effects of price, brand and store information on buyers' product evaluations. Journal of Marketing Research (JMR), 28 (3), 307-319.

Doyle, P., (2003). Değer temelli pazarlama, Çev: Gülfidan Barış, İstanbul: MediaCat Kitaplar.

Evanschitzky, H., Wangenheim, F., Woisetschlager, D. ve Blut, M. (2008). Consumer eth-nocentrism in the German market. International Marketing Review, 25(1), 7-32.

George, B.P. ve Yaoyuneyong, G. (2010), "Impulse buying and cognitive dissonance: a study conducted among the spring break student shoppers", Young Consumers: Insight and Ideas for Responsible Marketers, 11 (4), 291-306. 
Good, L.K. ve Huddleston, P. (1995). Ethnocentrism of Polish and Russian consumers: Are feelings and intentions related? International Marketing Review,12(5), 35-48.

Grewal, D., Monroe, K. B. ve Krishnan, R. (1998). The effects of price-comparison advertising on buyers' perceptions of acquisition value, transaction value and behavioral intentions. Journal of Marketing, 62(2), 46-59.

Hamin, H. ve Elliott, G. (2006). A less-developed country perspective of consumer ethnocentrism and "country of origin" effects: Indonesian evidence". Asia Pacific Journal of Marketing and Logistics, 18(2), 79-92.

Ha, C.L. (1998). The influence of consumer ethnocentrism and product characteristics on country of origin effects: a comparison between U.S. consumers and Korean consumer. (Doktora Tezi). Faculty Of The Graduate School Of The University Of Texas. Arlington.

Jiaxun, H ve Cheng Lu, W. (2015). Cultural identity and consumer ethnocentrism impacts on preference and purchase of domestic versus import brands: An empirical study in China. Journal of Business Research, 68(6), 1225-1233.

Jones, P. J. (1999). How to use advertising to build strong brands. Sage Publications: USA, California.

Karakaşoğlu, M. ve Arslan, M.G. (2016). Mağaza hizmet ortamının marka imajina ve satın alma niyetine etkisi: P\&B Ve H\&M örneği. Marmara Üniversitesi Öneri Dergisi, 12(46), 223-243.

Kavak, B. ve Gümüşlüoğlu, L. (2007). Segmenting food markets the role of ethnocent-rism and lifestyle in understanding purchasing intentions. International Journal of Market Research, 49(1), 71-94.

Kaynak, E. ve Kara, A. (2002). Consumer perceptions of foreign products. an analysis of product-country images and ethnocentrism. European Journal of Marketing, 36(7/8), 928-949.

Ker, M. (1998). Profesyonel imajın, imaj yönetimi kapsamındaki yeri ve önemi. Pazarlama Dünyası Dergisi,12 (71), 25-28.

Kim, H.B, Woo Gon K., Jeong A. AN. (2003). The effect of consumer-based brand equity on firms' financial performance. Journal of Consumer Marketing, 20(4), 335-35. 
Kinder, D. R. ve Kam C.D. (2012). Ethnocentrism as a short-term force in the 2008 American presidential election. American Journal of Political Science, 56 (2), 326-340.

Klein, J. G., Ettenson, R., Morris, M. D. (1998). The animosity model of foreign product purchase: An empirical test in the people's republic of China. Journal of Marketing, 62(1), 89-100.

Kocabaş F., Elden M., Yurdakul, N. (1999). Reklam ve halkla ilişkilerde hedef kitle. İstanbul: İletişim.

Kotler, P. (2009). Marketing management-european edition. Harlow, England: Pearson Prentice Hall Publishing.

Levine, R. ve Campbell, D.C. (1972). Ethnocentrism: Theories of conflict, ethnic attitudes and group behavior'. New York: John Wiley \& Sons, Inc.

Liang, X. ve Kong, Q. (2010). Cycle fluctiation research of consumer ethnocentrism segmentation in e-market of Chinese Mainland, IEEE. 978-1-4244-7159-1, Kasım.

Meydan, C. H. ve Şeşen, H. (2011). Yapısal eşitlik modellemesi AMOS uygulamaları (1 ed.). Ankara: Detay Yayınevi.

Mohammadzadeh, R. (2015). The effect of brand image and purchase intention on cosmetic products: Evidence from North Cyprus. Master of Arts in Marketing Management, Eastern Mediterranean University Gazimağusa, North Cyprus.

Moon, B.J. ve Jain, S.C. (2002). Consumer processing of foreign advertisements: Roles of coo perceptions, consumer ethnocentrism and country attitude. International Business Review, 11(2), 117-138.

Morrison, D. G. (1979). Purchase intentions and purchase behavior. Journal of Marketing, 43(2), 65-74.

Mutlu, H.M., Çeviker, A. ve Çirkin, Z. (2011). Tüketici etnosentrizmi ve yabancı ürün satın alma niyeti: Türkiye ve Suriye üzerine karşılaştırmalı analiz. Sosyoekonomi Dergisi, 8(1), 52-73.

Netemeyer, R. G., Durvasula,S., Lichtenstein, D.R. (1991). A cross-national assessment of the reliability and validity of the CETSCALE" Journal of Marketing Research, 28(3), 320-327.

Nunnally, J. C. (1978). Psychometric theory (2nd ed.). New York, NY: McGraw-Hill. 
Okechuku, C. (1994). The Importance of product COO. European Journal of Marketing. 28(4), 5-19.

Onurlubaş, E. (2018). Marka değeri boyutlarının marka bağlılığı ve satın alma niyeti üzerine etkisi: $X$ marka beyaz eşya kullanıcıları üzerine bir uygulama. Turkish Studies, Economics, Finance and Politics, 13(30), 273-302.

Onurlubaş, E., Öztürk, D. (2018). Market markalarında tüketicilerin gıda güvenliği algısı: Antalya ili örneği. Karagöz, R., Kodaman, T. ve Premović, M. (Editörler). Sosyal, Beşeri ve İdari Bilimlerde Akademik Çalışmalar. First Edition, September 2018, Ivpe Yayınları, Cetinje, Montenegro. 307-330.

Özçelik, G.D. ve Torlak, Ö. (2011). Marka kişiliği algısı ile etnosentrik eğilimler arasındaki ilişki: Levis ve Mavi Jeans üzerine bir uygulama. Ege Akademik Bakış, 11(3), 361-377.

Özdamar, K. (1999). Paket programlar ile istatistiksel veri analizi. Eskişehir: Kaan Kitabevi.

Özdamar K. (2004). Tabloların oluşturulması, güvenirlik ve soru analizi. Paket Programlarla İstatistiksel Veri Analizi-1. 5th ed. Eskişehir: Kaan Kitabevi.

Peltekoğlu, F.B. (2004). Halkla ilişkiler nedir? İstanbul: Beta.

Perry, A. ve Wisnom, D. (2004). Markanın DNA'sı esssiz ve dayanıklı markalar yaratmanın kuralları. Çev: Zeynep Yılmaz, İstanbul: Media Cat Kitaplari.

Petroshius, S.M. ve Kent B.M. (1987). Effect of product-line pricing characteristics on product evaluations. Journal of Consumer Research, 511519.

Pride, W.M. ve Ferrell, O.C. (2000). Marketing concepts and strategies. Houghton Mifflin Company, New York.

Randall, G. (2005). Markalaştırma: Stratejilerinizi planlamada doğru rehber. çev. Elif Özsayar, İstanbul: Rota Yayınları.

Raykov, T ve Marcoulides, GA. (2006). Fundamentals of Structural Equation Modeling. A First Course in Structural Equation Modeling. 2nd ed, London: Lawrence Erlbaum Associates, 41(3), 1-3.

Roth, M.S. ve Romeo, J.M. (1992). Matching product category and country 1mage perceptions: A framework for managing COO effects. Journal of International Business Studies, 3, 477-497. 
Salinas, E. A. ve Perez, J. M. P. (2009). Modeling the brand extensions' influence on brand image. Journal of Business Research, 62, 50-60.

Schiffman, L.G. ve Kanuk, L.L. (2000). Consumer behaviour. London: Prentice-Hall.

Shankarmahesh, M.N. (2006). Consumer ethnocentrism: An integrativereview of its antecedents and consequences. International Marketing Review 23(2), 146-172.

Sharma, S. ve Shin. J. (1995). Consumer ethnocentrism: A test of antecedentsandmoderators. Journal of the Academy of Marketing Science 23(1), 26-37.

Sharma, S. (1996). Applied multivariate techniques. John Wiley\& Sons Inc., Newyork.

Shimp, T.A. ve Sharma, S. (1987). Consumer ethnocentrism: Construction and validation of the CETSCALE. Journal of Marketing Research, 24(3), 280- 289.

Sipahi B., Yurtkoru, E.S., Çinko M. (2008). Sosyal bilimlerde SPSS ile Veri Analizi, İstanbul: Beta Yayınları.

Tabachnick, B.G. and Fidell, L.S. (2013). Using multivariate statistics. Pearson, Boston.

TÜIK, (2018). https://www.turkiye.gov.tr/turkiye-istatistik-kurumu-baskanligi-tuik

Vassella, M.C., Fountain, P.D., ve Fountain, U.K. (2010). Consumer ethnocentrism, patriotism global openness and country of origin effect: A literatüre review. ASBBS Annual Conference: Las Vegas, 17(1), 868-882.

Wang, H.Y. ve Tsai, F.C. (2014). The relationship between brand Image and purchase intention: Evidence from award winning mutual funds. International Journal of Business and Finance Research, 8(2), 2740.

Wang, C.L. and Chen Z.X. (2004). Consumer ethnocentrism and willingness to buy domestic products in a developing country setting: Testing moderating effects. Journal of Consumer Marketing, 21(6),391-400.

Witkowski, T.H. (1998). Consumer ethnocentrism in two emerging markets: determinants and predictive validity. Advances In Consumer Research, 25, 258-263. 
Xıogang B., Gunessee S., Hoffmann R., Hu1 W., Larner J., Qıng-Ping M., Thompson F. M. (2012). Chinese consumer ethnocentrism: A field experiment. Journal of Consumer Behaviour, 11, 252-263.

Yazıcı, İ. (1996). Kitle iletişiminde popüler imajlar, Marmara Üniversitesi Sosyal Bilimler Enstitüsü, İletişim Bilimleri, Yüksek Lisans Tezi. İstanbul.

Yıldırım, Y. ve Gültaş, P. (2016). Farklı etnik kimliklere sahip tüketicilerin etnosentrizm düzeylerinin ve ürün tercihlerindeki tutumlarının incelenmesi: Malatya ili örneği. International Journal of Academic Value Studies, 2 (6), 18-34.

$\mathrm{Yu}$, J.H. and Albaum, G. (2002). Sovereignty change influences on consumer ethnocentrism and product preferences: Hong Kong revisited one year later. Journal of Business Research, 55 (11), 891-899.

\section{Kaynakça Bilgisi / Citation Information}

Onurlubaş, E. ve Altunışık, R. (2019). Tüketici etnosentrizmi ve marka imajının satın alma niyeti üzerindeki etkisi: Gıda tüketicileri üzerine bir uygulama. OPUS-Uluslararası Toplum Araştırmaları Dergisi , 10(17), 277-307. DOI: 10.26466/opus.515217 